Frazer (Rritain) and Prof. M. J. L. Dols (The Netherlands), to discuss the present position with regard to the effect of dietary lipids on blood. The meeting was sponsored by the International Federation of Margarine Associations. In the first session Dr. H. J. Thomasson (Netherlands) presented investigations of blood lipids in a Trappist community under different dietary regimens. Dr. E. H. Ahrens, jun. (United States), discussed the possible mechanism of long-term blood lipid changes and described the investigations of his group into sterol balance. The second session was concerned with short-torm changes and papers were given by Dr. D. S. Fredrickson (United States), who described changes in blood lipid pattern resulting from alterations in the diet, with particular reference to lipoproteins, and by Dr. D. S. Robinson (Britain), who discussed the lipid transport function of lipoproteins and the possible role of lipolytic enzymes. The third session was devoted to a discussion on the effects of lipids on white blood cells and erythrocytes. Dr. P. Elsbach (United States) described the differences between the behaviour of granulocytes and macrophages towards lipids, and Dr. J. de Gier (The Netherlands) described some effects of fats on red blood cells.

In the final session, the possible effects of dietary lipids on blood platelets and blood coagulation were the subjects of discussion. Prof. G. V. Born (Britain) described the possible relationships between lipids and blood platelet behaviour and Prof. R. G. Macfarlane (Britain) discussed the blood-clotting mechanism and the possible points at which lipids might be expected to have some significant effoct.

In all, there were thirty-eight participants in the symposium, representing fifteen different countries. Original material presented at this meeting will be published independently by the respective authors in appropriate scientific journals.

\section{Pig Trypanosomiasis in Africa}

Pig trypanosomiasis, a possible source of human trypanosomiasis or 'sleeping sickness', is the subject of a monograph by Dr. L. E. Stephen, of the School of Public Health and Medicine of the American University, Beirut, Lebanon (Pig Trypanosomiasis in Africa. Commonwealth Bureau of Animal Health, Review Series No. 8. Farnham House, Farnham Royal, Buckinghamshire. 15s.). The review includes the geographical distribution of pig trypanosomiasis, the characteristics of the five species which infect the pig, and their mode of transmission, the chemotherapy and chemoprophylaxis of these infections, and an especially valuable chapter on the pig as a reservoir of human trypanosomiasis. Dr. Stephen concludes that further investigation is needed before any decision can be made on this point.

\section{South African Museum}

THE Minister of Education, Arts and Sciences decided that as from April 1, 1964, the South African Museum should consist of two sections: the South African Museum (Natural History) and the South African Museum (Cultural History). The Cultural History Section has moved into the old Supreme Court building. Two new galleries have been built for natural history, and extensions to the Marine Biology Department and a new palaeontological laboratory are in progress. Notable additions to the collection of photographs include prints of the Bushmen of Tsumkwe Pan, S.W. Africa, and a set of negatives of tribal studies taken $c .1900$.

\section{Technology and the U.S.S.R.}

IN a written answer to the House of Commons on May 24, Mr. Frank Cousins, the Minister of Technology, outlined his visit to the U.S.S.R. earlier that month and commented on his discussions with Mr. Kosygin on the value of exchange in science and technology between Britain and the U.S.S.R. He had visited the U.S.S.R. at the invitation of Academician V. A. Kirillin, chairman of the State Committee for Science and Technology, to discuss with representatives of the Soviet Government their methods for managing and deploying technological resources and for introducing new technology into industry. He had been able to see some of the advanced technological work being carried out in research institutes and discussed methods of training technologists. During his visit, Mr. Cousins and Mr. Kirillin had discussed tho organization and operation of the State Committee and its working relations with the Acaderny of Sciences, the Ministry of Higher Education and with Gosplan. Mr. Kirillin had described the methods used by the Soviet Government for allocating priorities to technological projects and for estimating their value, and for exploiting technological resources. He had also outlined the role of Soviet technology in economic planning, the training of qualified technologists and the dissemination of scientific and technological information.

\section{Surveying Sand and Gravel Resources}

IN a written answer in the House of Commons on May 26, the Minister of Land and Natural Resources, Mr. F. Willey, stated that he was giving priority to a survey of sand and gravel resources to the extent needed to supplement existing deposits potentially capable of economic exploitation. The Chelmsford and Ipswich areas were being studied first, and the aim was to establish potentially workable rescrves, a category between possible resources as shown on geological maps and resources proved by detailed exploration by the industry. The first, year's work would provide an opportunity to develop appropriate techniques and the field work would be done on an agency basis by the Institute of Geological Science.

\section{Grants for Research}

ON May 25 the Minister of State, Mr. G. Roberts, stated that of 1,078 applications for research grants to the Science Research Council in the fiscal year 1965-66, 832 were granted in whole or in part. For the Medical Research Council the corresponding figures were 516 and 377; for the Agricultural Research Council, 73 and 56 ; and for the Natural Environment Rescarch Council, 101 and 75 .

\section{Dipeptide Sequences}

Mr. Ben BLoom, of the National Institute of Arthritis and Metabolic Diseases, National Institutes of Health, Bethesda, Maryland, is seeking help in collecting informa. tion about amino-acid sequences in portions of polyamino-acid molecules. He is constructing a digital computer programme to evaluate the frequency of the occurrence of dipeptides and undertakes that information sent to him at Building 10 , Room $9 B-09$, National Institutes of Health, Bethesda, Maryland 20014, will be fully acknowledged in any publication that may eventually be made. Bloom's work is in part inspired by that of H. B. Bull (Arch. Biochem. Biophys., 112, 208; 1965), who found in an analysis of 1,304 dipeptides in eight protein molecules that, of the 400 possibilities, ten were favoured and eight occurred less frequently than would have been expected.

\section{University News:}

Belfast

Dr. Charles Dow has been appointed to the chair of comparative pathology, and Dr. H. B. Gilbody to a second chair of physics.

Liverpool

The University of Liverpool has just announced that Dr. K. McCarthy, senior lecturer in bacteriology, has been 